\title{
'More Online Quizzes, Please!' The Effectiveness of Online Quiz Tools in Enhancing the Learning of Grammar among ESL Learners
}

Vilogini Chandra Segaran \& Harwati Hashim

To Link this Article: http://dx.doi.org/10.6007/IJARBSS/v12-i1/12064

DOI:10.6007/IJARBSS/v12-i1/12064

Received: 13 November 2021, Revised: 18 December 2021, Accepted: 07 January 2022

Published Online: 29 January 2022

In-Text Citation: (Segaran \& Hashim, 2022)

To Cite this Article: Segaran, V. C., \& Hashim, H. (2022). 'More Online Quizzes, Please!' The Effectiveness of Online Quiz Tools in Enhancing the Learning of Grammar among ESL Learners. International Journal of Academic Research in Business and Social Sciences, 12(1), 1756-1770.

Copyright: @ 2022 The Author(s)

Published by Human Resource Management Academic Research Society (www.hrmars.com)

This article is published under the Creative Commons Attribution (CC BY 4.0) license. Anyone may reproduce, distribute, translate and create derivative works of this article (for both commercial and non0-commercial purposes), subject to full attribution to the original publication and authors. The full terms of this license may be seen at: http://creativecommons.org/licences/by/4.0/legalcode

Vol. 12, No. 1, 2022, Pg. 1756- 1770

Full Terms \& Conditions of access and use can be found at http://hrmars.com/index.php/pages/detail/publication-ethics 


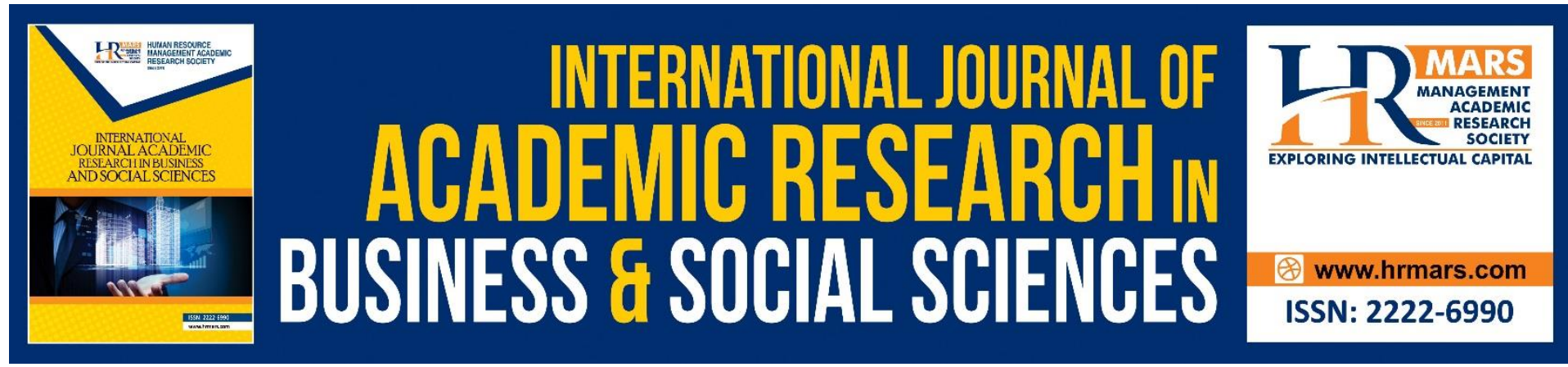

\title{
'More Online Quizzes, Please!' The Effectiveness of Online Quiz Tools in Enhancing the Learning of Grammar among ESL Learners
}

\author{
Vilogini Chandra Segaran ${ }^{1,2}$ \& Harwati Hashim ${ }^{2}$ \\ ${ }^{1}$ SK Ulu Semenyih, Selangor, Malaysia, ${ }^{2}$ Faculty of Education, University Kebangsaan \\ Malaysia
}

\begin{abstract}
The English language, is one of the most widely spoken and influential languages in the world and precisely grammatical rules are one of the most challenging aspects of learning a new language. English as Second Language (ESL) learners are prone to making grammatical errors. In accordance to this, using various online quiz tools into grammar lessons, like as Kahoot!, Quizizz, and Wordwall.net, can increase intrinsic and extrinsic motivation among students, making the sessions more interesting and relevant. Thus, this research aims to investigate the effectiveness of various online quiz tools in enhancing the learning of grammar among ESL learners. A mix-method research design applying an action research model was used in this study. Instruments such as pre-test, post-test and semi-structured interview were used to collect the needed data. Research participants involved in this research were 30 pupils of Year 3 from a rural school in Semenyih, Selangor, Malaysia. The findings showed that various online quiz tools were very effective in enhancing the learning of grammar among ESL learners. The scores obtained by the learners in their post-test compared to the pre-test showed significant improvement. Moreover, the learners perceived the use of various online quiz tools in learning grammar in a positive manner. Therefore, it is hoped that this research would provide new information and serve as a guideline for teachers who want to create engaging activities in teaching grammar for young learners.
\end{abstract}

Keywords: Online Quiz Tools, ESL Learners, Grammar, Rural, Kahoot, Quizizz, Wordwall.net

\section{Introduction}

English is one of the most widely spoken and influential languages in the world. English plays such an essential role in the world that it is difficult for anyone to disregard it completely (Jenkins, 2000). Listening, speaking, reading and writing are the four essential language abilities that we must acquire in order to communicate effectively in English. Grammar, in addition to these skills, is essential for language proficiency. Grammar is a set of rules or principles that govern the way a language works, as well as its system or structure (Brinton, 2000). According to Mestari and Malabar (2016), learners must have strong, accurate, and meaningful English grammar in order to communicate effectively in both spoken and written form. The mastery of a language's grammar will influence the mastery of linguistic skills. 
Malaysia is one of the nations where English is spoken officially and used as a communication tool. In Malaysia, English is taught as the second language (ESL) after the national language, Bahasa Malaysia (BM). ESL learners are learners whose first language or native language is not English and who require additional English language instruction to enhance their reading, writing, listening, and speaking skills (Goldenberg, 2008). The most common problem among Malaysian ESL learners is the inability to use proper English grammar despite the fact that English is taught and learned for several years from prekindergarten till the fifth form of secondary school (Kesumawati, Nor Zakiah, Norsimah \& Nor Hashimah, 2006). They also highlighted that a number of factors, including learners' learning techniques, motivation, teachers' teaching methods and syllabus might have contributed to this failure.

Some common mistakes made by the ESL learners are plural markers, difficulties in using determiners, incorrect use of tenses and lack of subject-verb agreement. Grammar is frequently regarded as the most difficult and boring skill to learn at any level of learning institution (Brindley, 1984; Baron, 1982). As a result, any mention of grammar in the classroom is likely to elicit apprehension among learners.

In a class, many teachers employ traditional strategies such as drilling, imitating, and memorization to teach grammar (Zhou, 2008; Ellis, 2012). On the other hand, teaching culture in the 21st century has broadened to include the incorporation of technology and educational tools in ESL classrooms (Sumardi et al., 2020). Based on research conducted by Khairul (2018), findings showed that almost all English teachers agreed that their learners preferred fun learning over traditional teaching techniques. Similarly, when compared to traditional teaching and learning methods, learners are more favorable towards online quizzes in terms of ease of use, engagement, involvement, and interaction (Hillman, 2012).

The inability to use proper English grammar among ESL learners can be reduced using suitable instructional strategies and approaches. The online quiz is one of the techniques that may be utilized to produce enjoyable and engaging grammar lessons due to the integration of technology to support a successful pedagogy. The online quiz is an online application used as a means of e-assessments using technology in a classroom (Cohen \& Sasson, 2016). It encourages learners' attendance, participation, and feedback on their learning.

Many prior studies have focused on learners' participation, engagement and performance with the use of online quiz but there were very limited studies on the effectiveness of various online quiz tools: Kahoot, Quizizz and Wordwall.net in improving grammar among pupils in a rural school in Malaysia. Thus, this research aims to investigate the effectiveness of various online quiz tools in enhancing grammar among ESL learners. The first objective of this research is to study the effect of various online quiz tools in improving learners' understanding of grammar among ESL learners meanwhile the second research objective is to obtain pupils' perception towards the use of various online quiz tools in enhancing the learning of grammar among ESL learners.

\section{Literature Review}

This section discusses the grammar in ESL Learning, theoretical support on Piaget's meaningful learning and Krashen's affective filter and also on relevant previous studies based on Technology Acceptance Model (TAM). 


\section{Grammar in ESL Learning}

The cornerstone of a language's competence is its mastery of grammar (Wang, 2010). Language does not exist without grammar. It is also difficult for learners to communicate effectively in English without first understanding English grammar. Learners can enhance their integrated English proficiency and raise their overall English levels if they have a strong understanding of grammar (Haugan, 2018). Without proper grammar knowledge, it is difficult to communicate views and thoughts clearly and concisely. Many learners, both inside and outside the classroom, are unable to articulate precise sentences due to a lack of proper grammar.

There are some common errors in grammar made by ESL learners. Based on research conducted by Nezami and Najafi (2012), it was found that punctuation, lexical/word choice, spelling, article, verb formation, usage of plurals, preposition, verb tense, clause structure (aberrant sentence), and the subject/verb agreement were the ten most common mistake categories among the ESL Learners. Another research conducted by Singh, Razak \& Ravinthar (2017) found similar findings. Subject-verb agreement, verb tense, noun, preposition, adjective, article, pronoun, adverbs, and conjunction were among the grammar errors found based on the learners' written reports. They highlighted that among all of the grammatical errors mentioned, the most common or prevalent errors made by learners in their English writing were errors in Subject-Verb Agreement. Learners encounter such errors in their written work because they were unable to incorporate the proper Subject-Verb Agreement, indicating the learners' difficulty in constructing sentences correctly. Majority of learners struggled with the agreement since they couldn't make the subjects and verbs agree because they matched the singular subject to the plural verb incorrectly and vice versa.

Different teachers have different methods and approaches in teaching grammar. Effective teaching enhances learners' performance in acquiring a language. Therefore, this study focuses on the use of various online quiz tools in enhancing the learning of grammar among ESL learners.

\section{Related Learning Theories}

Learning theories are a set of ideas that explain how people remember, recall, and learn information. There are five main educational learning theories that educators can utilize to help them enhance their classrooms and make them better learning environments for all learners: Cognitive Learning Theory, Behaviourism Learning Theory, Constructivism Learning Theory, Social Learning Theory and Humanism Learning Theory. These theories of learning are briefly described in Table 1, adapted and summarised from Ashworth, Brennan, Egan, Hamilton \& Sáenz (2004).

Table 1: Summary of learning theories 
INTERNATIONAL JOURNAL OF ACADEMIC RESEARCH IN BUSINESS AND SOCIAL SCIENCES Vol. 12, No. 1, 2022, E-ISSN: 2222-6990 @ 2022 HRMARS

\begin{tabular}{|l|l|l|l|}
\hline $\begin{array}{l}\text { Learning } \\
\text { Theories }\end{array}$ & Theorists Pearning Process & Purpose \\
\hline Behaviourism & $\begin{array}{l}\text { Skinner, Pavlov, } \\
\text { Thorndike }\end{array}$ & Change in behaviour & $\begin{array}{l}\text { Produce behavioural } \\
\text { change } \\
\text { direction) }\end{array}$ \\
\hline Cognitivism & $\begin{array}{l}\text { Bruner, Piaget, } \\
\text { Kohler }\end{array}$ & $\begin{array}{l}\text { Internal Mental } \\
\text { processes }\end{array}$ & $\begin{array}{l}\text { Develop capacity and } \\
\text { skills to learn better }\end{array}$ \\
\hline Constructivism & Piaget, Vygotsky & $\begin{array}{l}\text { Construction of } \\
\text { meaning from } \\
\text { experience }\end{array}$ & $\begin{array}{l}\text { Construct knowledge } \\
\text { Social }\end{array}$ \\
Vygotsky, Piaget & $\begin{array}{l}\text { Interaction and } \\
\text { observation in a } \\
\text { social context }\end{array}$ & $\begin{array}{l}\text { Model new roles and } \\
\text { behaviour }\end{array}$ \\
\hline Humanism & Maslow, Rogers & $\begin{array}{l}\text { A personal act to } \\
\text { fulfill potential }\end{array}$ & $\begin{array}{l}\text { Become self-actualized, } \\
\text { autonomous }\end{array}$ \\
\hline
\end{tabular}

In accordance with this, this research caters to the Cognitivism theory, which integrates the Jean Piaget's Meaningful Learning and Krashen's affective filter. The inability to use proper English grammar among ESL Learners can be resolved by providing a meaningful environment and proper guidance to the learners. This is linked to Piaget's Game-Based Learning Theory, which emphasises the need of meaningful learning. Another theory that supports meaningful learning is the Krashen's affective filter. According to Krashen, the acquisition of a second language can be acquired if comprehensible input is given to the learners and low affective filter to allow the input 'in'. This encompasses of anxiety level, selfconfidence, attitude and motivation as cited by Xiaoyan (2009). Therefore, the integration of various online quiz tools in teaching grammar provides a meaningful context for learners to learn grammar in a more fun and engaging environment with a high level of excitement.

\section{Technology Acceptance Model (TAM)}

This research is based on the Technology Acceptance Model (TAM), which involves two important elements: ease of use and perceived usefulness of technology. Davis (1989) created the TAM model as shown in Figure 1 below in order to investigate the impact of technology on users' behaviour.

Figure 1: Technology Acceptance Model

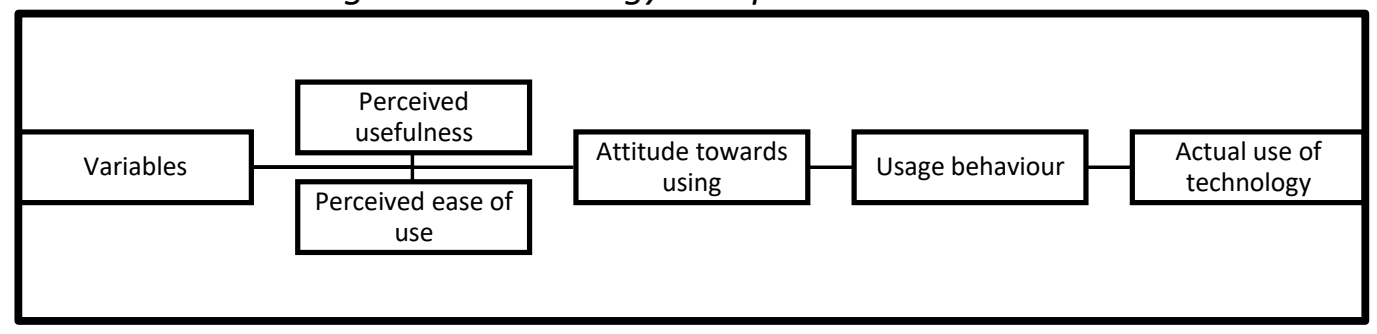

According to the model, the perceived usefulness and ease of use of technology are the two most important aspects that influence an individual's attitude towards the use of technology. Perceived usefulness refers to the user's opinion in utilizing technology to improve his or her performance, whereas perceived ease of use refers to the user's opinion that using technology is easy and convenient (Davis, 1989). 


\section{Past Studies on Online Quiz Tools}

Technology has always been an amazing tool in education to improve learners' motivation and engagement. Many studies have shown positive findings indicating that online quizzes increase learners' participation and improve the learning experience.

A case study was conducted by Bicen and Kocakoyun (2018) entitled Perceptions of Learners for Gamification Approach: Kahoot. The findings revealed that using a gamification technique improved learners' interest in the lesson and their desire to succeed. This approach was also discovered a positive outcome towards learners' motivation level. In addition, the findings of this study also showed that the gamification technique has an effect on learners, making them more ambitious and driven to learn. Similarly, a study conducted by Md Yunus and Azmanuddin (2019) discovered that gamification has an impact on students' learning, particularly memory retention. The results revealed a substantial change after the students were exposed to Kahoot! as a tool for learning (and remembering) English irregular verbs.

Göksün and Gürsoy (2019) investigated gamification activities that are utilised as a formative evaluation tool in learning based on learners' academic achievement and engagement. In this research, it was found that Kahoot and Quizizz showed positive results towards learners' engagement and achievement during their formative assessment. However, it was also found that Quizizz was less effective compared to Kahoot. Contrarily, Jalani and Hashim (2020) highlighted that Quizizz helped the learners in a rural school to achieve better in their academic performance. The quasi-experimental research found that learners' performance in their post-test showed tremendous improvement after the application of Quizizz as an online formative assessment.

Martín-Sómer et al (2021) stated that the use of Kahoot! motivated the learners during online classes in the lockdown period caused by Covid 19. The findings revealed that students regarded the use of Kahoot!, as beneficial in maintaining their attention throughout online classes and thus helped in improving their level of learning. The data analysis also demonstrated that high involvement was observed during online classes, implying that the use of Kahoot in lessons resulted in an increase in final grades. In addition to that, Kaur and Nadarajan (2020) revealed that almost all the students had favourable experiences with Kahoot!. Kahoot! was created to assist students in becoming more engaged and active participants in their language learning processes, as well as to assist teachers in providing more relevant and complete language learning experiences for their students.

Iwamotoet al (2017) found similar findings as the results showed that students who used Kahoot scored significantly higher on high-stakes exams than students who did not. It's believed that pedagogical tools like Kahoot can help students do better in examinations at college and university. Students that used Kahoot showed positive behaviour, and the findings of this study also imply that having a joyful and engaging environment can help students do better in school.

In short, it's essential to carry out this research to investigate the effectiveness of various online quiz tools in improving grammar among ESL learners based on the Technology Acceptance Model (TAM) with underpinning theories of Piaget's Meaningful Learning and Krashen's affective filter theory.

\section{Methodology}

This section further explains the research design used in this study, research participants, instruments, data collection method and data analysis procedure. 


\section{Research Design}

The objective of this research is to investigate effect of various online quiz tools in enhancing the learning of grammar among ESL learners and to obtain pupils' perception towards the use of various online quiz tools. This research employs a mix-method research design, applying the action research model: Kemmis and McTaggart (1988) model. This research design is appropriate because this research was conducted up to 3 cycles with three different quiz tools (Kahoot!, Quizizz, Wordwall.net) involving different grammar elements (Verbs to be, Preposition of time, Singular vs Plural nouns) for each cycle.

\section{Research Participants}

Research participants involved in this research were 30 pupils of Year 3 from a rural school in Semenyih, Selangor, Malaysia. The proficiency level of these pupils in grammar is low and intermediate. These participants obtained a band three and below for their schoolbased assessment (SBA) for English, categorized as the weak and intermediate performance level.

\section{Instruments}

Pre-test, post-test and semi-structured interview were used as the instruments to gather the needed data. A pre-test was conducted before the teaching and learning of grammar, whereas a post-test was conducted after they had learned the grammar element with the integration of 3 online quiz tools: Kahoot, Quizizz and Wordwall.net. Three different sets of pre and post-test had been administered, focusing on the verb to be (am, is, are), preposition of time (on, in, at), singular and plural nouns. The pre-test and post-test consist of 10 questions for each grammar element. The chosen grammar elements were based on the Year 3 'Get Smart' Malaysian Textbook.

The researcher employed focus group interviews semi-structured interview protocols. The replies were recorded and translated into English. The use of mother tongue language was allowed during the interview session enabling weak learners to contribute relevant information in relation to this study.

\section{Data Collection}

The procedure of the research is based on the Kemmis and McTaggart (1998) Model. This study was conducted up to 3 cycles as shown below: 
Figure 2: Procedure of data collection up to 3 cycles

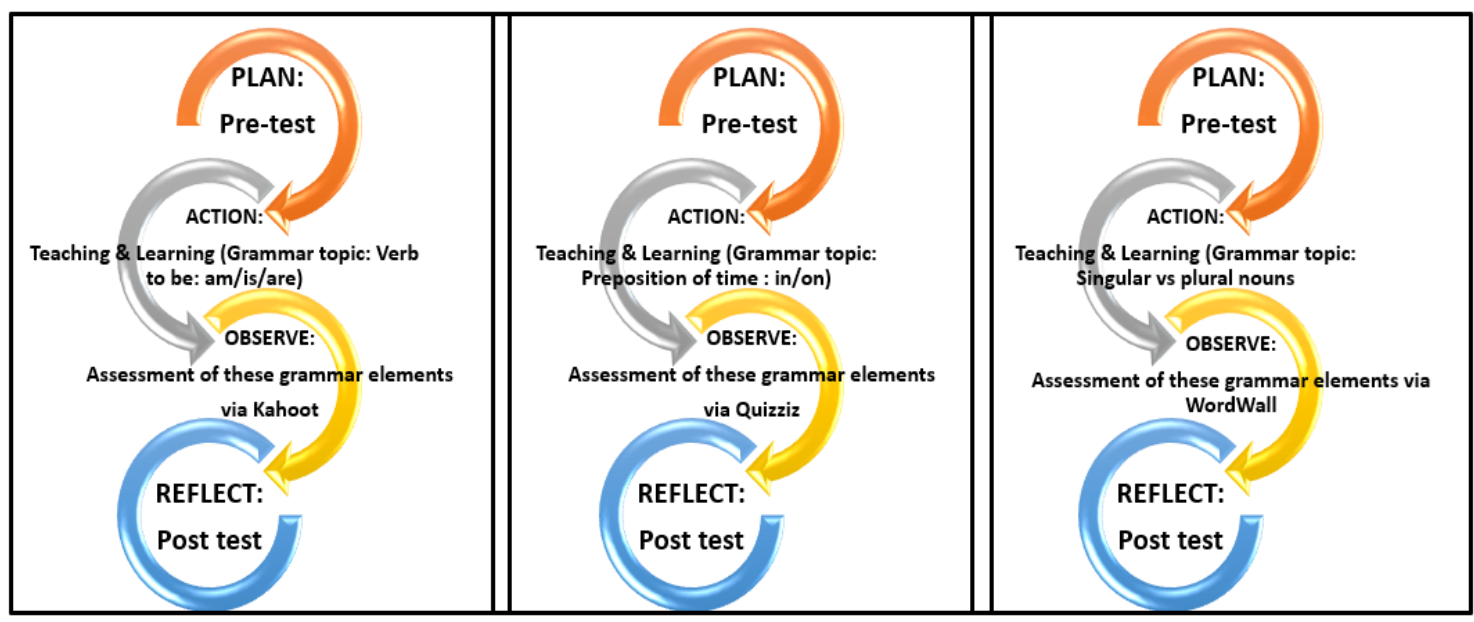

This research was conducted for up to 4 weeks. In the $1^{\text {st }}$ week, the learners sat for the pre-test on the $1^{\text {st }}$ grammar element: verb to be (am, is, are). The researcher taught the learners on the usage of the verb to be in detail and later assigned them with Kahoot Game to assess their understanding. A post-test was conducted after the session and a comparison of the pre-and post-scores was made. The same procedure was applied for the $2^{\text {nd }}$ and $3^{\text {rd }}$ week for the rest of the grammar elements: preposition of time using Quizizz and Singular vs Plural Nouns using Wordwall.net. A semi-structured focus group interview was conducted on the $4^{\text {th }}$ week to gain information on the usage and effectiveness of these online quizzing tools in learning grammar. Their responses were recorded and transcribed. Results and responses were treated with the utmost confidentiality.

\section{Data Analysis}

Data collected from pre and post-test were marked and scores were recorded. The data was then presented in a table (pre and post-test scores) for each grammar element to make a comparison on the effectiveness of various online quizzes in learning grammar. Meanwhile, data gathered through the interview were transcribed and analyzed based on thematic coding. The relevant information was categorized into themes such as fun learning, source of motivation, learning guidance and learning preferences.

\section{Findings}

This section explains the findings obtained from pre-test, post-test and interview. The first research objective: The Effect of Various Online Quiz Tools in Enhancing the Learning of Grammar were studied based on the data obtained from pre-test and post-test. A pre-test and post-test were conducted with a group of pupils with 3 different grammar focus (Verb to be, Preposition of Time and Singular Vs Plural Nouns). The following were the results. 


\section{Data from Pre-Test and Post-Test}

A. Grammar Focus: Verb to be

Table 2: Pre and Post Test scores for the verb to be

\begin{tabular}{|l|l|l|}
\hline \multirow{2}{*}{ Range of scores/marks } & Number of students (f) & \\
\cline { 2 - 3 } & Pre-Test & Post-Test \\
\hline $\mathbf{0}$ & 13 & - \\
\hline $\mathbf{1 - 2}$ & 11 & - \\
\hline $\mathbf{3}-\mathbf{4}$ & 6 & 3 \\
\hline $\mathbf{5}-\mathbf{6}$ & - & 10 \\
\hline $\mathbf{7 - 8}$ & - & 9 \\
\hline $\mathbf{9 - 1 0}$ & - & 8 \\
\hline $\mathbf{N = 3 0}$ & & \\
\hline
\end{tabular}

Table 2 shows the pre and post-test scores obtained by the learners before and after the use of Kahoot Tool. The grammar focus was on the verb to be (am, is and are). Based on the table above, it can be concluded that learners improved significantly from pre-test to post-test results. It was discovered that 13 pupils received a score of 0 on their pre-test, followed by 11 pupils who had a score of 1 to 2, 6 students received a score of 3 to 4 , and none received a score of 5 and above. Contrarily, all the pupils scored 3 and above during their post-test after using the Kahoot tool, with 3 of them scoring 3 to 4, followed by 10 pupils scoring 5 to 6,9 pupils scoring 7 to 8 , and 8 pupils scoring 9 to 10 . None of them received a score of 0 to 2 for their post-test.

B. Grammar Focus: Preposition of Time

Table 3: Pre and Post Test scores for Preposition of Time

\begin{tabular}{|l|l|l|}
\hline \multirow{2}{*}{ Range of scores/marks } & Number of students (f) & \\
\cline { 2 - 3 } & Pre-Test & Post-Test \\
\hline $\mathbf{0}$ & 7 & - \\
\hline $\mathbf{1 - 2}$ & 11 & 3 \\
\hline $\mathbf{3}-\mathbf{4}$ & 10 & - \\
\hline $\mathbf{5}-\mathbf{6}$ & 1 & 5 \\
\hline $\mathbf{7 - 8}$ & - & 14 \\
\hline $\mathbf{9 - 1 0}$ & - & 8 \\
\hline $\mathrm{N}=30$ & & \\
\hline
\end{tabular}

The second grammar focus was the preposition of time with the incorporation of Quizizz as the online quiz tool. According to table 3, about 7 of them received a score of 0,11 received a score of 1-2, 10 received a score of 3 to 4 , and just 1 had a score of 5 to 6 . All of them received a score of 4 and below for their pre-test. Positive results can be noted in their post-test scores after using the Quizizz Tool to study the preposition of time. The number of students who received a score of 1 to 2 dropped from 11 to 3 . In their post-test, 5 pupils received a score of 5 to 6,14 received a score of 7 to 8 , which is the highest and 8 received a score of 9 to 10 . This demonstrates that 27 of them scored 5 and above after the use of Quizizz for their post-test. However, 3 of them still scored 1 to 2 for their post-test. Regardless, none of them received a zero for their post-test.

c. Grammar Focus: Singular vs Plural Nouns 
Table 4: Pre and Post Test scores for Singular vs Plural Nouns

\begin{tabular}{|l|l|l|}
\hline \multirow{2}{*}{ Range of scores/ marks } & Number of students (f) & \multicolumn{2}{|l|}{} \\
\cline { 2 - 3 } & Pre-Test & Post-Test \\
\hline $\mathbf{0}$ & 10 & - \\
\hline $\mathbf{1 - 2}$ & 9 & - \\
\hline $\mathbf{3 - 4}$ & 7 & 2 \\
\hline $\mathbf{5 - 6}$ & 4 & 5 \\
\hline $\mathbf{7 - 8}$ & - & 14 \\
\hline $\mathbf{9 - 1 0}$ & - & 9 \\
\hline $\mathrm{N}=30$ & & \\
\hline
\end{tabular}

The 3rd grammar focus was Singular and Plural Nouns integrating the Wordwall.net tool. In comparison to the rest of the score range, the number of pupils who scored zero for the pre-test was the highest (10 pupils). Following that were 9 pupils who received a score of 1 to 2,7 pupils who received a score of 3 to 4 , and 4 pupils who received a score of 5 to 6 . None of them scored 7 and above for their pre-test. Pupils' post-test scores improved significantly after using the Wordwall.net in the classroom to teach grammar. None of them received a score of 0 to 2; instead, they scored three and above. Two of them received a 3-4 score, while five pupils scored 5-6 marks. In their post-test, the number of pupils who scored between 7 and 8 was the highest, with 14 pupils scoring between 7 and 8 and 9 pupils scoring between 9 and 10 .

\section{Data from Interview}

The second research objective: Pupils perception towards the use of various online quiz tools in learning grammar were studied based on the data obtained through an interview. A semi-structured interview was conducted with a group of pupils. The information gathered from these students was divided into themes such as fun learning, source of motivation, learning guidance and learning preferences. The following were the results:

\section{Fun Learning}

The participants perceived Kahoot!, Quizizz and Wordwall.net as an easy-to-use platform that makes learning more fun. The gamification features in Kahoot! were mentioned by the participants as promoting fun learning. Based on the data gathered, it was discovered that all the players felt really joyful and excited when playing Kahoot, Quizizz, and Wordwall.net. They found these online quiz tools entertaining and enjoyable. The learners' participation throughout online quiz sessions was overwhelming. The learners' attendance improved gradually during English lessons. All of them were very happy and they enjoyed answering questions using these online quiz tools. Some of the responses based on the data collected:

- "I feel happy. Fun". (Participant 2)

- "I like it". (Participant 1)

- "I enjoy it". (Participant 9)

- "Saya suka. Best, cikgu". (I like it. It feels good.) (Participant 13)

Many said they have prior knowledge and experience with these online tools. Nine participants claimed that they have previously played with online quiz tools such as Kahoot, Quizizz, and Wordwall.net before: 'Yes, I've played before'. Another six participants stated 
that this was their first time using these online quiz tools: 'No, this is my first time. I have never played before'.

\section{Source of Motivation}

The participants considered the Kahoot!, Quizizz and Wordwall.net sessions motivational. The sessions emphasised continuous learning, review, and in-depth learning. The competition in Kahoot! sessions increased their motivation, which increased their selfconfidence and encouraged them to participate in more sessions. The elements such as music, visuals, points, competitiveness, and leader boards were the elements which enticed the students to play these games as highlighted by the participants:

- "I like the pictures and the answers". (participant 11).

- "Because we get to play live and we get to compete with our friends" (participant 6).

- "It's due to the points. We get more points if we answer the questions correctly. Sometimes, we get double points" (participant 15).

\section{Learning Guidance}

The participants believed that the online quiz sessions provided learning guidance. They stated that the Kahoot!, Quizizz and Wordwall.net offered opportunities for feedback, self-reflection and self-assessment. They were able to improve their understanding of grammar as a result of the sessions. The interactive nature of Kahoot! was enhanced by the real-time response; as a result, students received immediate feedback on which questions they had answered correctly and incorrectly. All of the participants agreed that the online tools Kahoot, Quizizz, and Wordwall.net were highly helpful in learning grammar. The following were some of the reasons mentioned by the participants:

- "If we made a mistake, then we get to see the correct answers on the screen immediately" (participant 1).

- "If I made a mistake in answering the quizzes, I get to know the answers and I did not repeat the same mistake when asking questions in my workbook/ exercise book." (Participant 9)

\section{Learning Preferences}

Participants preferred to learn grammar with technology. Online quizzes are a great way to turn a stressful situation into a fun one. All the participants preferred to learn grammar through these online quiz tools rather than with their textbooks and workbooks. These participants preferred the integration of technology, music, visuals and rewards in their learning rather than drilling techniques such as copying grammar rules in their books. Below were some of the responses given by the participants:

- "Through games, teacher. I don't like to copy and write everything in our books."

(Participant 13)

- "I prefer online quizzes because we get more marks and points, unlike doing exercises

in our exercise/workbook, marks are not being allocated" (Participant 7)

- "Because I get to click on the answers via online quiz unlike copying in the exercise book, it hurts my hands" (Participant 2)

\section{Discussion}

The first research questions which guides the analysis of the findings: Are various online quiz tools effective in improving learners' understanding of grammar among ESL learners? The findings of this study showed that various online quiz tools were very effective 
in increasing ESL learners' grammar understanding. It was discovered that various online quiz tools helped learners do better in grammar based on the data obtained from pre-test, posttest and interview.

According to the data obtained from pre-test and post-test scores for all three grammatical elements, the pupils demonstrated a significant improvement after using these online quiz tools with Kahoot, Quizizz and Wordwall.net tools. The data collected via pre and post-test corresponds to the data collected via semi-structured interview. The results of this study indicated that the elements such as gamification techniques, rewards and scores, immediate feedbacks, music and graphics involved in these online quiz tools helped the pupils to learn grammar better. Gamification applications have been rationalized as essential for pupils as it allows pupils to think and allow for a competitive environment. Points, awards, and leader boards are commonly employed in gamification to motivate the pupils and to change the desired behaviour (Bicen \& Kocakoyun, 2018).

This was due to the fact that Kahoot, Quizizz and Wordwall.net includes prizes in the form of scores, which encourages players to successfully answer all the questions. Game-play (gamification) approaches contributed to learners' interest and improved learning which aids memory retention. According to the findings of a study by Yunus and Azmanuddin (2019), it was revealed that gamification is a popular teaching method that can greatly enhance the teaching and learning experience. Precisely, Kahoot was efficient in helping younger English language learners to retain memory on English irregular verbs.

Apart from that, several customized quizzes offered on Wordwall.net, such as balloon pop, maze chases, whack-a-mole, random wheel, game show quiz, and others which kept them involved and motivated them to perform well. Learning through games is an appropriate teaching and learning activity for preschool and primary school kids, according to (Sang, 2013). According to Martín-Sómer et al (2021), Kahoot encourages student participation by rewarding accurate answers with greater scores and placing them the top of the ranking list.

Moreover, online quizzes involved the use of relevant content, giving students with quick feedback (immediate feedback). Self-quiz provides immediate feedback, which is important in an e-learning environment. Immediate feedback helps learners to correct their mistakes, and many scientific research has discovered that immediate feedback can help learners keep their interest and motivation (Bognár et al., 2021). According to Epstein et al (2002), the Immediate Feedback Assessment Technique (IF AT) actively engages learners in the discovery process enhancing retention and corrections of initially incorrect answers.

The second research questions which guides the analysis of the findings: How do pupils perceive the use of various online quiz tools in enhancing the learning of grammar among ESL learners? During the interview, all the participants acknowledged that these online quiz games helped them learn grammar more effectively as it promoted fun learning. The students claimed that it made learning grammar more enjoyable and interesting and that it was also due to the scores, which encouraged them to read the questions carefully and select the best answers. According to the findings of a study conducted by Iwamoto et al (2017), having a cheerful and engaging environment can help pupils do better in school. The experimental group believed that Kahoot was an excellent instructional tool since the students found it fascinating and engaging. Students in the experimental group were spotted having a wonderful time and displaying excitement, particularly when their screen names appeared on the leader board. 
The major source of motivation that anticipated the learners in these online quiz sessions were the elements such as music, visuals, points, competitiveness, and leader boards. Many students stated that they prefer to learn grammar through online quiz since they receive more points and may compete with their peers. This is most likely due to the learners' learning style since they enjoy the sense of competitiveness among their peers and the incorporation of technology into their lessons. The online quiz keep track of each student's responses, assigns points, and ranks players based on their speed and accuracy (Bicen \& Kocakoyun, 2018).

Furthermore, these various online quiz tools act as learning guidance to the learners. It provided possibilities for self-reflection, self-assessment, and feedback. They highlighted that immediate feedback allowed them in determining which questions they had answered correctly and wrongly. This actually helped them to retain the rules of the grammar at ease. Jalani \& Hashim (2020) stated that the usage of Quizizz as a tool for online formative evaluation was perceived well by the ESL students. This aided the kids' language acquisition, retention of their memory as well as their academic performance.

According to the interview, everyone agreed that using online quiz tools to learn grammar was preferable to using textbooks (participants' learning preferences) solely. The use of technology in learning and teaching has proven to be an effective way of connecting with students' learning styles. Every kid had different learning styles and technology allows teachers to accommodate these differences (Bernard et al., 2017) as cited by Kaur and Nadarajan (2020). Furthermore, the use of technology can shift old passive learning models into more active learning modes allowing dynamic teaching and learning.

\section{Conclusion}

In conclusion, this study examined the effectiveness of various online quiz tools in enhancing the learning of grammar among ESL learners and it was discovered that various online quiz tools assisted the learners in learning grammar at ease. The findings showed that various online quiz tools were very effective in enhancing the learning of grammar among ESL learners and significant improvement were seen in their post-test scores. The learners obtained better scores in their post-test compared to their pre-test. Moreover, the learners perceived positive responses towards the use of various online quiz tools in learning the grammar. The evidence from this study suggests that these online quiz tools can be an excellent platform for motivating students to learn English precisely grammar in an exciting and engaging setting through the use of technology in accordance with 21st-century teaching and learning strategies. The findings reported here shed new light that various online quizzes trigger intrinsic and extrinsic motivation among learners to compete with their peers to obtain better scores and ranks.

This study can serve as a guideline for teachers who want to create engaging activities in teaching grammar for young learners. Limited access to the internet and technology was the limitation involved in this study as the pupils were from a rural area with poor backgrounds. In spite of this limitation, regardless of the pupils' background, all pupils were excited in answering questions with these various online quiz tools even with limited internet access and gadgets. Therefore, further study can be conducted as experimental research, using a different online or offline quiz, with a larger sample and with different grammar elements. 


\section{References}

Ashworth, F., Brennan, G., Egan, K., Hamilton, R., \& Sáenz, O. (2004). Learning theories and higher education.

Baron, D. (1982). Grammar and good taste: Reforming the American language. New Haven, NJ: Yale University Press.

Bicen, H., \& Kocakoyun, S. (2018). Perceptions of learners for gamification approach: Kahoot as a case study. International Journal of Emerging Technologies in Learning, 13(2).

Brindley, G. (1984). Needs Analysis and Objective Setting in the Adult Migrant Education Program. NSW Adult Migrant Education Service, Sydney.

Brinton, J. L. (2000). The Structure of Modern English: A Linguistic Introduction. The Netherland: John Benjamin Publishing Co.

Bognár, L., Fauszt, T., \& Váraljai, M. (2021). The Impact of Online Quiz on Student Success. International Journal of Emerging Technologies in Learning, 16(11).

Cohen, D., \& Sasson, I. (2016). Online quiz in a virtual learning environment as a tool for formative assessment. JOTSE, 6(3), 188-208.

Davis, F. (1989). Perceived Usefulness, Perceived Ease of Use, and User Acceptance of Information Technology. MIS Quarterly, 13(3),319.

Ellis, R. (2012). A lifetime of grammar teaching. Teaching English in the Two Year College, 40(1), 7.

Epstein, M. L., Lazarus, A. D., Calvano, T. B., Matthews, K. A., Hendel, R. A., Epstein, B. B., \&

Brosvic, G. M. (2002). Immediate feedback assessment technique promotes learning and corrects inaccurate first responses. The Psychological Record, 52(2), 187-201.

Göksün, D. O., \& Gürsoy, G. (2019). Comparing success and engagement in gamified learning experiences via Kahoot and Quizizz. Computers \& Education, 135, 15-29.

Goldenberg, C. (2008). Teaching English language learners: What the research does-and does not-say.

Haugan, J. (2018). The importance of formal grammar skills: Reflections on Polish learners learning Norwegian.

Hillman, J. (2012). The impact of online quiz on student engagement and learning.

Iwamoto, D. H., Hargis, J., Taitano, E. J., \& Vuong, K. (2017). Analyzing the efficacy of the testing effect using Kahoot ${ }^{\mathrm{TM}}$ on student performance. Turkish Online Journal of Distance Education, 18(2), 80-93.

Jalani, N. A. B. M., \& Hashim, H. B. (2020). Quizziz: ESL Learners' Perceptions in Rural School. International Journal of Scientific and Research Publications, 10, 23-27.

Jenkins, J. (2000). The phonology of English as an international language. Oxford University Press.

Kaur, P., \& Nadarajan, R. (2020). Language learning and teaching using Kahoot. International Journal of Modern Education, 2(5), 19-28.

Kesumawati, A. B., Zakiah, N. A. H., Norsimah, M. A., \& Hashimah, N. J. (2006). First language influence on second language performance: A study of common English grammatical errors among rural secondary school students. Online. Retrieved May 27, 2021, from http://repo.uum.edu.my/3259/1/Ke1.pdf

Khairul, Y. (2018). Challenges Of Teaching Grammar at Tertiary Level: Learning from English Lecturers' Insights. (7):149-159.

Martín-Blas, T., \& Serrano-Fernández, A. (2009). The role of new technologies in the learning process: Moodle as a teaching tool in Physics. Computers \& education, 52(1), 35-44. 
Martín-Sómer, M., Moreira, J., \& Casado, C. (2021). Use of Kahoot! to keep students' motivation during online classes in the lockdown period caused by Covid 19. Education for Chemical Engineers.

Yunus, M., \& Azman, A. B. M. (2019). Memory Stay Or Stray?: Irregular Verbs Learning Using Kahoot!. Arab World English Journal (AWEJ) Special Issue on CALL, (5).

Mestari, S. A., \& Malabar, F. (2016). The use of authentic materials in teaching grammar for EFL students (teachers' perspective). Language and Language Teaching Journal, 19(02), 125-131.

Nezami, A., \& Najafi, M. S. (2012). Common Error Types of Iranian Learners of English. English Language Teaching, 5(3), 160-170.

Singh, C. K. S., Singh, A. K. J., Razak, N. Q. A., \& Ravinthar, T. (2017). Grammar Errors Made by ESL Tertiary Learners in Writing. English Language Teaching, 10(5), 16-27.

Sumardi, L., Rohman, A., \& Wahyudiati, D. (2020). Does the Teaching and Learning Process in Primary Schools Correspond to the Characteristics of the 21st Century Learning?. International Journal of Instruction, 13(3), 357-370.

Wang, F. (2010). The Necessity of Grammar Teaching. English Language Teaching, 3(2), 78-81.

Xiaoyan, D. (2009). The affective filter in second language teaching. Asian Social Science, 5(8), 162-165.

Zhou, K. (2008). "An inductive approach to English grammar teaching." HKBU Papers in Applied Language Studies 12: 1-18. 